\title{
Residential water demand modeling in Queensland, Australia: A comparative panel data approach
}

\begin{abstract}
This paper uses monthly data from eleven local governments to model residential water demand in Queensland, Australia from 1994 to 2004. In the sample, residential consumption is charged using a variety of structures including fixed charges without allowance, fixed charges with allowance and excess rates, two-part tariffs comprising an access charge and a flat consumption rate and multi-part tariffs with an access charge and two or more limits with increasing consumption rates. Water demand is specified as average monthly household water consumption and the demand characteristics include the marginal and average price of water and daily average maximum temperatures and rainfall. The findings confirm residential water as price inelastic, more responsive to average than marginal prices, and more responsive to changes in temperature than rainfall. The results also suggest that cross-sectional variation in demand is related to local government-specific factors.
\end{abstract}

Keywords: Residential water pricing; demand management; Australia; two-part tariffs

\section{Introduction}

In 1994 the Strategic Framework for the Efficient and Sustainable Reform of the Australian Water Industry was endorsed by the Council of Australian Governments (COAG). After acknowledging that Australia is the driest continent, and that a substantial proportion of public investment is tied up in water infrastructure, the basic premise of these reforms was the protection of water as a precious resource, and the recognition that ongoing improvements in national productivity could only be achieved through an efficient and sustainable water industry with incentives to prevent water wastage.

In terms of residential water pricing, the reforms required the introduction of two-part tariffs (where cost-effective) with fully transparent community subsidies (if any) and the minimal free allocation of water. In practice, these COAG-initiated industry reforms mostly led to water-pricing structures based on a tariff comprising a fixed charge reflecting the cost of the service provision and a variable charge based on the volume of water purchased. But since local governments or councils as the principal providers of residential water supplies in Australia fall under state legislative control, every state and territory was then compelled to consider the way it would reform water service charges as part of this agreement with the Commonwealth Government. 
In Queensland, Australia's third most populous state, reforms were first introduced in 1997 for the seventeen largest local governments with significant water business activities through amendments to the Local Government Act 1993. But rather than making it mandatory for these councils to adopt twopart tariffs, the legislation required them to assess by December 1998 whether it was cost-effective form of water pricing for their own areas [cost-effectiveness related to the cost of introducing metering relative to the saving in future infrastructure]. Through the National Competition Policy Financial Incentive Package, the State Government assisted Queensland councils with the costs of conducting reviews and rewarded progress with implementing the reforms. By 2002/2003 most of the State's larger local governments had adopted two-part tariffs for water services.

However, the State Government did not legislate to require smaller local governments to consider or adopt water pricing reforms. As a consequence, there is wide variation in water pricing structures across Queensland's one hundred and twenty-five local governments [There are seven legal forms of water supply businesses in Queensland: Shire Councils, City/Town Councils, Local Government Owned Corporations, Joint Local Government Organizations, Government Department Licenser, Government Owned Corporations and Corporations Law Companies (McKay, 2007). McKay (2005; 2006 ; 2007) provides a useful discussion of the impact of water governance regimes on water pricing and policy in Australia, arguing that the different types of bodies and their different policies make achievements heterogeneous and cooperation between the bodies difficult]. Of course, such reforms need to be considered in the context of the increasing scarcity of water supplies and climate change in Queensland. Currently, Brisbane's water catchments are at the lowest level of capacity (34.1\%) of any Australian capital city. At the same time, Queensland is becoming increasingly warmer and drier with suggestions that average annual temperatures could be $2^{\circ} \mathrm{C}$ hotter, and average annual rainfall $15 \mathrm{~mm}$ lower, by 2030 (Department of Natural Resources and Mines, 2005).

\section{Objectives of Analysis}

Clearly, there are very dissimilar water pricing systems in Queensland that reflect very different policy objectives, at least at the local level. But a single factor that determines the performance of all is the price elasticity of demand. Since the price elasticity of demand determines the quantity response of consumers to changes in price it lies at the core of efforts to restrain water consumption, through its impact on revenue, the viability and sustainability of water utility services, and through its distributional impacts, the fairness and equity of water supplies.

Accordingly, the primary purpose of this paper, part of a project conducted jointly by the Queensland Department of Natural Resources and Mines and the Queensland University of Technology, is to provide measures of the price elasticity of residential water demand in Queensland, Australia. This provides a key input into optimal tariff design and demand side management strategies. A second purpose is to assay the impact of the introduction of two-part tariffs on residential water consumption. This allows an assessment to be made of the potential impacts of the recent policy 
changes regarding water pricing structures. The objectives (and techniques and assumptions) of this paper are then clearly similar to other work on residential water demand modeling, including Arbués et al. (2004), Billings \& Agthe (1980), Creedy et al. (1998), Higgs \& Worthington (2001), Hoffmann et al. (2006), Höglund (1999), Martínez-Espiñeira (2003), Nieswiadomy (1992), Renwick \& Archibald (1998), Rietveld et al. (2000) and Thomas \& Syme (1988), amongst others.

\section{Data Context}

The information gathered by local governments concerning their residential water supplies is generally restricted to information provided annually to the Queensland Department of Local Government, Planning, Sport and Recreation. Even so, there is little consistency in the provision of this information; there is a wide range of interpretation and little attempt at standardizing the data gathering process. In order to overcome these deficiencies, medium to large local governments were approached individually with a request for information on their water pricing and non-pricing structures and monthly residential water consumption and the number of connections. While more than a few local governments were willing to provide the information requested, in many cases the information provided was either incomplete or of very low frequency. Eleven local governments provided suitable data: Beaudesert Shire Council, Bowen Shire Council, Caloundra City Council, Cooloola Shire Council, Dalby Town Council, Gold Coast City Council, Mount Isa City Council, Noosa Shire Council, Rockhampton City Council, Stanthorpe Shire Council and Warwick Shire Council. These local governments represent about nine percent of the local governments in Queensland.

Monthly household consumption and connection data was provided by each of these local governments. However, the sample period for each council (number of monthly time-series observations in brackets) varies. The end date for all series is August 2004 with Caloundra, Dalby, Noosa and Stanthorpe starting in July 1994 (122), Rockhamption in September 1994 (120), Cooloola in October 1994 (119), Warwick in January 1995 (116), Bowen in July 1995 (110), Gold Coast in February 1996 (103), Mount Isa in July 1998 (74) and Beaudesert in July 1999 (62). The eleven councils accordingly provide a total of 1,192 monthly observations. A snapshot of the eleven local governments in 2002/2003 is provided in Table 1 in terms of their Australian local government classification, geographic location and climate, demographics and water pricing structures. Figure 2 depicts their geographic location.

For the eleven local councils included there are four different pricing structures as at 2002/2003: a fixed charge with unlimited allowance (Rockhampton); a fixed charge with a free allowance followed by some excess charge for consumption over a particular level (Bowen); a two-part tariff consisting of a fixed access charge and a cost per unit based on the volume of water consumed (Beaudesert, Caloundra, Gold Coast, Noosa, Stanthorpe and Warwick) or a cost per unit that increases when consumption reaches certain thresholds, in such a way that the tariff consists of sequence of marginal 
prices for different consumption blocks (Cooloola. Mt. Isa and Dalby). Respective examples are (\$ are Australian dollars with $100 \notin$ per dollar): Rockhampton has a fixed charge of $\$ 472$ per annum for water with an unlimited allowance; Bowen has a fixed charge of $\$ 450$ per annum, with a free allowance up to 750 kilolitres and $75 \notin$ cents per kilolitre for consumption above 750 kilolitres; the Gold Coast has a fixed charge of $\$ 190$ and $70 \notin$ per kilolitre and Cooloola has a fixed charge of $\$ 190$ per annum, $42 \notin$ per kilolitre for the first 290 kilolitres and $116 \notin$ thereafter. The analytical technique used in this paper accommodates these different pricing structures.

\section{Variable Specification}

The dependent variable is the average monthly quantity of water demanded per household served by a local government supplier $(D M D)$. Data for households is collected monthly and includes the total residential consumption and number of residential connections for each local council. With this information in hand, average monthly water demand per household is calculated.

The first independent variable specified is the price of water $(P C E)$. Initially, the marginal price of water is used in a marginal price model specification. The marginal price is widely used in estimating water demand equations under increasing block pricing structures (Agthe \& Billings, 1987; Hewitt \& Hanemann, 1995; Martínez-Espiñeira, 2003; Higgs \& Worthington, 2001; Hoffmann et al. 2006). The demand equations are then re-estimated using the average price in an average price model specification. A key feature of demand side management policies is clearly the pricing structure and a variety of alternative forms have been employed in Australia and elsewhere (Dinar and Subramanian, 1998; Bartoszczuk and Nakamori, 2004). The incorporation of both marginal and average prices in this study is intended to address both the alternating use of these measures in the literature, and the argument that consumer understanding of the average price is often better than the marginal price Regardless, a negative sign is hypothesized when water consumption is regressed against the marginal price or the average price.

The remaining two independent variables are for weather and temperature. These have been shown to influence residential water use in a number of ways. The amount of rainfall $(R A N)$ measured in millimeters $(\mathrm{mm})$, for example, has an influence on garden watering, and also on other activities such as washing cars and laundry (Agthe \& Billings, 1987; Barkatullah, 1996; Dany et al., 1997; Hoffmann et al. 2006). It is expected that higher rainfall will lead to lower external water consumption. Temperature $(T M P)$ in degree Celsius $\left({ }^{\circ} \mathrm{C}\right)$ has also been shown to influence water consumption, with hotter days inferring higher consumption through increased garden watering and topping-up of swimming pools (Nieswiadomy, 1992; Dandy et al., 1997; Martínez-Espiñeira , 2003; Hoffmann et al., 2006). Monthly weather information is sourced from the Australian Bureau of Meteorology.

Table 2 presents a summary of descriptive statistics across the eleven local councils. Sample means, standard deviations, minimums and maximums, are reported. As shown, household monthly water consumption per connection averaged 47.05 kilolitres across all councils. Across all local 
councils, the marginal water price averaged $37.24 \phi$ per kilolitre, average price per kilolitre (in cents) is $82.07 \not \subset$ and the average daily rainfall and maximum temperature are $2.63 \mathrm{~mm}$ and $26^{\circ} \mathrm{C}$, respectively. As also shown in Table 2, average monthly water consumption is the lowest for Stanthorpe, Caloundra and Beaudesert with 23.79, 30.55 and 30.97 kilolitres respectively and highest for Bowen, Rockhampton and Mount Isa with 81.44, 90.68 and 110.56 kilolitres respectively. The lowest marginal prices per kilolitre are Rockhampton $(0.00 \phi)$, Bowen $(16.92 \phi)$ and Stanthorpe $(17.23 \phi)$, and the highest are in Gold Coast (55.53ф), Noosa (67.45ф) and Caloundra (75.34ф). Average prices per kilolitre vary from $39.58 \notin$ in Rockhampton to $100.14 \varnothing$ in Noosa. Lastly, average daily rainfall ranges from $1.02 \mathrm{~mm}$ (Bowen) to $4.08 \mathrm{~mm}$ (Noosa) per month and the average daily maximum temperature is the highest in Mount Isa (31.65 degrees) and lowest in Stanthorpe (21.43 degrees).

Table 3 compares the means of the variables under fixed and fixed with excess tariffs and two-part and multi-part tariffs (most of councils changed their tariff structures to the latter during the sample period). Levene's test for equality of variances determines whether the test for equality of means assumes equal or unequal variances. With the exception of the daily temperature the variances are unequal as are the means. As shown, the quantity demand is significantly lower under two-part/multipart tariffs and marginal and average prices are significantly higher. Average daily rainfall is also significantly higher in areas using two-part/multi-part tariffs.

\section{Model Specification}

The time-series data supplied by each local council on water consumption is combined to form a panel or pooled data set as a combination of time-series and cross-sectional observations. There are a number of ways that can be used to incorporate the structure of pooled data in estimating demand equations for water. The estimated model may have a common, fixed or random intercept term. With panel data, both the fixed and random effects specifications estimators provide improvement over the simple linear or common effects regression model which does not take account of the cross-sectional characteristics of each local council. In the fixed effects specification, the council specific effects are assumed to be fixed parameters. In the random effects specification, the councils are assumed to comprise of a random sample and the council specific effects are assumed to be independently distributed with a mean of zero and a constant variance.

\section{Common Effects Regression Model}

In the common effects regression model where all the data for the eleven local councils are pooled together, a simple assumption is that the parameters do not vary across sample observations. The basic motivation for pooling time-series and cross-sectional data is that if the model is properly specified, pooling produces more efficient estimates. In the common effects model, it is assumed that water consumption is homogeneous across local councils. The common effects model can be written as: 


$$
D M D_{i t}=\alpha_{1}+\beta_{1} P C E_{i t}+\beta_{2} R A N_{i t}+\beta_{3} T M P_{i t}+e_{i t}
$$

where $i(i=1,2, \ldots, 11)$ refers to each council, $t\left(t=1,2, \ldots, T_{\mathrm{i}}\right)$ are monthly observations (in this unbalanced panel, $T_{\mathrm{i}}$ ranges between 62 and 122), the dependent and explanatory variables are previously defined, $\alpha_{1}$ is the intercept term which is common across all cross-sections, $\beta \mathrm{s}$ are the slope coefficients to be estimated and the $e_{i t}$ are independent and identically distributed random variables with $\mathrm{E}\left(e_{i t}\right)=0$ and $\mathrm{E}\left(e_{i t}{ }^{2}\right)=\sigma_{e}^{2}$.

\section{Fixed Effects Regression Model}

Two additional pooling models considered are the fixed effects (or dummy variable) model and the random effects (or error components) model. To start with, the fixed effects model allows the intercept term to vary across the local councils. Dummy variables are introduced to take account of the differences in the level of water consumption across the local councils. The fixed effects model can be represented as:

$$
D M D_{i t}=\sum_{i=1}^{N} \alpha_{i} L C_{i t}+\beta_{1} P C E_{i t}+\beta_{2} R A N_{i t}+\beta_{3} T M P_{i t}+e_{i t}
$$

where $\alpha_{i}$ represents the intercept coefficient for the $i$ th cross-sectional local council, $L C_{\text {it }}$ are dummy variables that take a value of unity for observations belonging to the ith local council and zero otherwise. All other variables are previously defined. This specification is usually employed when specifying a different intercept coefficient for each cross-sectional unit can adequately capture differences in crosssectional units. That is, cross-sectional identifiers explain changes from local council to local council.

\section{Random Effects Regression Model}

An alternative to the fixed effects model is a random effects model that assumes that the coefficients are random variables drawn from some larger population:

$$
D M D_{i t}=\alpha_{1}+\beta_{1} P C E_{i t}+\beta_{2} R A N_{i t}+\beta_{3} T M P_{i t}+u_{i}+e_{i t}
$$

where $\mathrm{E}\left(u_{i}\right)=0, \mathrm{E}\left(u_{\mathrm{i}}^{2}\right)=\sigma_{u}^{2}, \mathrm{E}\left(u_{i} u_{j}\right)=0$ for $i \neq \mathrm{j}, \mathrm{E}\left(u_{i} e_{i t}\right)=0$ and all other variables are as previously defined. The structure of the model is such that, for a given local council, the correlation between any two disturbances in different time periods is the same, and unlike a first-order autoregressive model, does not decline as the disturbances become farther apart in time. Further, not only is the correlation constant over time, it is identical for all local councils. The inference is that the results from this model may be generalized to the population from which the sample is taken.

In this manner, the distinction between the random and fixed effects can be viewed as the distinction between conditional and unconditional inference. With the fixed effects model, inference is conditional on the local councils in the sample, whereas the random effects model is more appropriate when we are interested in (unconditional) inferences about a larger population. But where the number of cross-sections 
$(N)$ is relatively small and the number of time series $\left(T_{\mathrm{i}}\right)$ is relatively large, as in the current analysis, the results of the two models may not differ significantly.

\section{Reliability Testing}

The procedures used to carry out reliability tests between the models are as follows. Firstly, the model is estimated using common coefficients, and tested against the fixed and random effects specifications using an $F$-test. The $F$ ratio used for the test is:

$$
F\left(n-1, \sum_{i}^{N} T_{i}-n-K\right)=\frac{\left(R_{u}^{2}-R_{p}^{2}\right) /(n-1)}{\left(1-R_{u}^{2}\right) /\left(\sum_{i}^{N} T_{i}-n-K\right)}
$$

where $u$ indicates the unrestricted model (fixed or random effects) and $p$ indicates the pooled or restricted model with only a single overall constant term (common effects). Under the null hypothesis there are no fixed local council specific effects against the alternative that there are local council specific effects. Rejection of the null implies that the common effects estimators are biased and spurious.

The second test is used to choose between a fixed or random effects specification. This is accomplished using a Hausman test. Under this hypothesis, there are two sets of estimates; one of which is consistent under both the null and alternative hypothesis, and another that is consistent only under the null. The null hypothesis is that both the fixed and random specifications are consistent, whereas under the alternative the fixed effect model is, but the random effects model is not. The test is based on a Wald criterion:

$$
W=\chi^{2}(K)=[b-\hat{\beta}]^{\prime}\left[\operatorname{Var}(b)-\operatorname{Var}(\hat{\beta}]^{-1}[b-\hat{\beta}]\right.
$$

where $b$ is the vector of estimated slope coefficients from the fixed effects model and $\hat{\beta}$ is the vector of estimated slope coefficients from the random effects model and $\operatorname{Var}(b)$ and $\operatorname{Var}(\hat{\beta})$ are the corresponding variance covariance matrices and $W$ is asymptotically distributed as chi-squared with $K$ (number of explanatory variables) degrees of freedom.

\section{Empirical Results}

Table 4 provides the estimated coefficients, standard errors and $p$-values of the null hypothesis of the parameters individually are equal to zero and elasticities (at the means) of the parameters detailed in the common, fixed and random effects regression models. The upper panel of Table 4 presents the results of a specification with marginal price while the lower panel includes the average price. Columns 1 to 4 present the estimated results of the common effects model. The results of the fixed effects and random effects models are detailed in columns 5 to 8 and 9 to 12 respectively. Also 
included in Table 4 are statistics for $\mathrm{R}^{2}$ and adjusted $\mathrm{R}^{2}$ and F-statistics and $p$-values for the joint hypothesis test that all slope coefficients are zero.

Panel data estimation is first specified using common effects. To test for multicollinearity, variance inflation factors (VIF) are calculated (not shown). As a rule of thumb, a VIF greater than ten indicates the presence of harmful collinearity. Among the independent variables the highest VIF is for the marginal price (5.09). This suggests that multicollinearity, while present, will not considerably bias the estimated coefficients. The adjusted $\mathrm{R}^{2}$ of 0.391 suggests the common effects model has relatively high explanatory power. Since the data are mainly time-series and limited cross-sectional in nature, the presence of heteroskedasticity or non-homogeneity of variances of the regression disturbances is likely: least squares estimates are inconsistent if heteroskedasticity is evident. Accordingly, the estimated heteroskedastic consistent covariance matrix is calculated for an unknown form of heteroskedasticity.

The model first discussed is the common effects specification across all councils with the marginal price specification. The estimated coefficients for all parameters are significant at the $1 \%$ level of significance. Using the $F$-statistic the null hypothesis that all slope coefficients are jointly zero is also rejected at the $1 \%$ level. Across all local councils, the greatest effects on water consumption are temperature (3.515) and rainfall (-2.718). All elasticities are calculated at the means. The price elasticity of demand is -0.112 (inelastic) indicating that a $10 \%$ increase in the price of water is associated with a $1.12 \%$ decrease in the quantity of water demanded. In household level modeling when either multi-part tariffs or fixed with excess structures are employed, the price associated with the marginal unit of consumption introduces endogeneity. The price coefficient is biased downward since the marginal price and quantity are codetermined by the rate structure.

In all models using the marginal price, the demand is estimated as if it were conditional on remaining in the same block range, and hence the price elasticity estimated is also conditional on changes in demand being small enough that a household remains in the same block range. An analogous issue pertains to models using aggregate data. When the proportion of households consuming in a block range is not modeled, the distribution of households across the blocks is embedded in the elasticity estimate, and the elasticity is, at best, a conditional elasticity. In the common effects model with the marginal price specification, the elasticities for the rainfall and temperature parameters indicate that a $10 \%$ increase in rainfall is associated with a $1.52 \%$ decrease in water consumption, while a $10 \%$ increase in temperature is associated with a $19.39 \%$ increase in water consumption per household per month.

In the fixed effects model with the marginal price specification, all three coefficients are significant at the $10 \%$ level of significance or lower. The estimated coefficient for the marginal price is positive which lies contrary to economic expectations. The price elasticity of demand is 0.016 (elastic) indicating a $10 \%$ increase in price is associated with a $0.16 \%$ increase in water consumption. Similar results were obtained by Barkatullah (1996), and Hewitt \& Hanemann (1995), when estimating water 
demand equations in the presence of increasing block rates. Accordingly, the estimate of the marginal price variable is biased upwards. Instrumental variable estimation could be used to address this problem. However, in order to use instrumental variable estimation the number of exogenous variables has to be greater than the number of endogenous variables. Unfortunately, there are insufficient exogenous variables to permit the use of instrumental variables in this analysis. The results for the random effects model are similar to the fixed effects model. Regrettably, the equations using fixed and random effects, even with high explanatory power, cannot be reliably used to predict demand for water across local councils in Queensland.

The models are then re-estimated using average prices. This follows the suggestion that rather than the quantity demanded being determined by the marginal price, households make decisions on water consumption using the average price; that is, they include the fixed or access charge in their decisions. As shown in Table 3, average prices in the sample for fixed and fixed with excess charge structures are nearly six times larger than marginal prices and 63\% large than marginal prices in two-part and multi-part structures. The adjusted $\mathrm{R}$ squares for the average price specifications are higher than the marginal price specifications in all three - common, fixed and random effects estimations, thus indicating the average price specification models have better explanatory power.

The demand equations with an average price specification, the calculated $F$ test ( $p$-value) for the fixed effects and random effects over the common effect model are $565.542(0.000)$ and $482.279(0.000)$ respectively. In both cases, the null hypothesis that there are no council-specific effects is rejected. The Hausman test in (5) is used to compare the fixed and random effects models. Under the null hypothesis both the fixed and random specifications are consistent, whereas under the alternative the fixed effect model is, but the random effects model is not. The Wald value calculated for the water demand model is 6905.473 across all local councils and is larger than the critical value of 23.6848 (chi-square with fourteen degrees of freedom at the $5 \%$ level of significance), thus the null hypothesis can be rejected. The fixed effects specification out performs the common and random effects models. Only the results for the fixed effects model are presented.

For the fixed effects model with an average price specification, the estimated coefficients for all parameters are significant at the $1 \%$ level of significance or lower and all estimated parameters conform to a priori expectations. Using the $F$-statistic the null hypothesis that all slope coefficients are jointly zero is also rejected at the $1 \%$ level. Across all councils, the largest effects on water consumption are temperature and rain fall. The price elasticity of demand is -0.126 (inelastic) indicating that a $10 \%$ increase in the price of water is associated with a $1.26 \%$ decrease in the quantity demanded. By way of comparison, Agthe \& Billings (1987) calculated a price elasticity of -0.56 , Barkatullah (1996) -0.21 , Dandy et al. (1997) -0.78, Garcia \& Reynaud (2004) -0.25 and Gaudin et al. (2001) -0.47. In a recent study, Hoffmann et al. (2006) calculated a price elasticity of -0.56 for Brisbane. If rainfall increases by $10 \%$ per month, water consumption will decrease by $0.60 \%$ per household per month. With a $10 \%$ increase in temperature, water consumption will increase by $4.86 \%$ per household per month. 
The final part of the analysis estimates the impact of two-part tariffs on these parameters. The results of a fixed effects specification including average prices are included in Table 5. The basic premise used here is that the introduction of two-part tariffs has impacted upon the level of water consumption (intercept) and the responsiveness of water consumption to price, temperature and rainfall (slope). The introduction of two-part tariffs in each council is specified using a dummy variable that takes a value of one for months where two-part tariffs are in place and zero otherwise. As shown a $1 \notin$ per kilolitre increase in average prices is ordinarily associated with a 0.06 kilolitre (60 liters) fall in the quantity of water demanded per month per household. However, under two-part tariffs the same price increase is associated with an additional 0.14 kilolitre (140 liters) decrease. The two-part tariff interaction parameters for temperature and rainfall are not significant. This indicates that the presence of two-part-tariffs have no impact on the responsiveness of the quantity of water demanded to changes in environmental variables: that is, the major impact offered by two-part tariffs is the price change and that consumers can more clearly identify the change in average prices with two-part tariffs than with alternative tariff structures. Importantly, since Queensland consumers react more to average than marginal prices, and since average prices are higher than marginal prices, there is the suggestion is that consumers are under-consuming because of misperception of the pricing parameter. One possibility is that the non-price restraints on consumption in Queensland councils during most of the sample period are raising the effective price of water relative to the actual price, primarily for discretionary water use.

\section{Conclusion}

The present study uses common, fixed and random effects panel data regression models to estimate household residential water demand across eleven local councils in Queensland, Australia. The data is supplied directly by each council, where almost all have introduced two-part or multi-part tariffs consisting of a fixed access charge with no free entitlement of water and a constant (or increasing) consumption charge per kilolitre. The remaining councils have retained either a fixed or fixed with excess charge for water.

Several outcomes are associated with the introduction of two-part and multi-part tariffs in Queensland. First, mean marginal prices have increased from $12 \varnothing$ to $64 \varnothing$ (433\%) a kilolitre while average prices (including access charges) have increased from $60 \varnothing$ to $105 \varnothing(75 \%)$. By itself, this would suggest that the quantity of water demanded by all households should have fallen. However, the evidence presented suggests that since households appear to make consumption decisions on the basis of average prices, the percentage change in quantity demanded is not as great as it would have been with marginal prices. As a result, the average level of consumption under two-part tariffs, holding marginal and average prices constant, is higher than under fixed and fixed with excess structures. Part of this is associated with household water consumption and the implementation of two-part tariffs trending up at the same time, but part also indicates that the two-part tariff systems in place may not be 
optimal. For example, in inclining multi-part tariff structures, consumption rates are so low, and the limits so high, there is almost no meaningful price signal. Moreover, the reliance on high access charges in two-part tariffs structures means there is likely to be much misperception of the marginal price of water and this further distorts outcomes.

Second, the price elasticity of demand is relatively inelastic at -0.126 . This implies that the price mechanism, at present, is not an effective tool for managing the demand and consumption of residential water. Depending upon the model specified a $10 \%$ increase in the price of water is associated with only a $1.26 \%$ reduction in the quantity demanded. One possibility is that non-price controls on discretionary consumption (garden watering, hosing of hard surfaces, car-washing, filling and topping-up of swimming pools) in most Queensland councils effectively limit the impact of price changes on non-discretionary (laundry, bathroom and kitchen) and discretionary consumption. That is, the quantity of water demanded is unable to be increased with price reductions and households are operating close to a low level of non-discretionary consumption.

Third, it is found that there are factors beyond the control of water authorities that also have an influence on residential water demand. The results indicate that consumption varies strongly with temperatures and somewhat less strongly with rainfall. However, there is also sizeable cross-sectional variation in consumption that is unrelated to environmental factors and closely linked with unique council factors. An obvious candidate is non-price controls such as watering restrictions set in place by individual councils to manage demand. Unfortunately, insufficient data was available to explore this possibility.

Finally, since this study takes a demand-side approach, detailed comment cannot be made on supply-side decisions like the setting of access charges and consumption rates. However, there is arguably unusually wide variation in the marginal and average prices for residential water in Queensland, even from geographically adjacent jurisdictions. This is a cause for concern in that the pricing structures in place may be more reflective of a desire for administrative convenience, revenue stability and political expediency rather than any desire to improve the efficient and sustainable use of residential water supplies. This is deserving of further inquiry.

\section{References}

Agthe, D. \& Billings, R. (1987). Equity, price elasticity, and household income under increasing block rates for water. American Journal of Economics and Sociology, 46(3), 273-286.

Arbués, F., García-Valiñas, M. \& Martínez-Espiñeira, R. (2003). Estimation of residential water demand: A state of the art review. Journal of Social Economics, 32(1), 81-102.

Barkatullah, N. (1996). OLS and instrumental variable price elasticity estimates for water in mixed-effects model under multiple tariff structure. Report 226, Department of Economics, University of Sydney. (April 2002 reissue by London Economics) 
Bartoszczuk, P. and Nakamori, Y. (2004). Modeling sustainable water prices. in Handbook of Sustainable Development Planning: Studies in Modelling and Decision Support, Quaddus, M. and A. Siddique (eds), Edward Elgar Publishers: Cheltenham, UK.

Billings, R. B. \& Agthe, D. E. (1980). Price elasticity for water: A case of increasing block rates. Land Economics, 56(1), 73-84.

Creedy, J., van de Ken, J. \& McKenzie, K. (1998). The demand for water by single-metered and group metered households. Australian Economic Review, 31(3), 203-210.

Dandy, G., Nguyen, T. \& Davies, C. (1997). Estimating residential water demand in the presence of free allowances. Land Economics, 73(1), 125-139.

Department of Natural Resources and Mines (2005). Climate Smart Adaptation: What Does Climate Change Mean for You? Queensland Government, Brisbane.

Dinar, A. \& Subramanian, A. (1998). Policy implications from water pricing in various countries. Water Policy, $1,239-250$.

Garcia, S. \& Raynaud, A. (2004). Estimating the benefits of efficient water pricing in France. Resource and Energy Economics, 26(1), 1-25.

Gaudin, S., Griffin, R. \& Sickles, R. (2001). Demand specification for municipal water management: Evaluation of the Stone-Geary form. Land Economics, 77(3), 399-422

Hewitt, J. \& Hanemann, W. (1995). A discrete/continuous choice approach to residential water demand under block rate pricing. Land Economics, 71(2), 173-192.

Higgs, H. \& Worthington, A. (2001). Consumer preferences and charging options in a large urban municipality: A case study. Public Works Management Policy, 5, 209-207.

Hoffmann, M., Worthington, A. \& Higgs, H. (2006). Urban water demand with fixed volumetric charging in a large municipality: The case of Brisbane, Australia. Australian Journal of Agricultural and. Resource. Economics, 50(3), 347-359.

Höglund, L. (1999). Household demand for water in Sweden with implications of a potential tax on water use. Water Resource Research, 35, 3853-3863.

Martínez-Espiñeira, R. (2003). Estimating water demand under increasing-block tariffs using aggregate data and proportions of users per block. Environmental Resource Economics, 26(1), 5-23.

McKay, J.M. (2005) Water institutional reforms in Australia. Water Policy, 7(1), 35-52.

McKay, J.M. (2006). Issues for CEO's of water utilities with the implementation of Australian water laws. Journal of Contemporary Water Research and Education, 135, 115-130.

McKay, J.M. (2007). Water governance regimes in Australia: Implementing the National Water Initiative. Water, Journal of the Australian Water Association, 34(1), 150-156.

Nieswiadomy, M. (1992). Estimating urban residential water demand: Effects of price structure, conservation and education. Water Resource Research, 28(3), 609-615.

Renwick, M. \& Archibald, S. (1998). Demand side management policies for residential water use: Who bears the conservation burden? Land Economics, 74(3), 343-359.

Rietveld, P., Rouwendal, J. \& Zwart, B. (2000). Block rate pricing of water in Indonesia: an analysis of welfare effects. Bulletin of Indonesian Economic Studies, 36(3), 73-92. 
Thomas, F. \& Syme, G. (1988). Estimating residential price elasticity of demand for water: A contingent valuation approach. Water Resource Research, 24(2), 1847-1857. 
Table 1. Snapshot of selected local government areas, 2002/2003.

\begin{tabular}{|c|c|c|c|c|c|c|c|c|c|c|c|}
\hline & $\begin{array}{c}\text { Beaudesert } \\
\text { Shire } \\
\text { Council }\end{array}$ & $\begin{array}{l}\text { Bowen } \\
\text { Shire } \\
\text { Council }\end{array}$ & $\begin{array}{l}\text { Caloundra } \\
\text { City } \\
\text { Council }\end{array}$ & $\begin{array}{l}\text { Cooloola } \\
\text { Shire } \\
\text { Council }\end{array}$ & $\begin{array}{c}\text { Dalby } \\
\text { Town } \\
\text { Council }\end{array}$ & $\begin{array}{c}\text { Gold Coast } \\
\text { City } \\
\text { Council }\end{array}$ & $\begin{array}{c}\text { Mount } \\
\text { Isa City } \\
\text { Council }\end{array}$ & $\begin{array}{l}\text { Noosa } \\
\text { Shire } \\
\text { Council }\end{array}$ & $\begin{array}{l}\text { Rockhamp- } \\
\text { ton City } \\
\text { Council }\end{array}$ & $\begin{array}{l}\text { Stanthorpe } \\
\text { Shire } \\
\text { Council }\end{array}$ & $\begin{array}{l}\text { Warwick } \\
\text { Shire } \\
\text { Council }\end{array}$ \\
\hline ACLG & UFM & RAV & URL & URM & URS & URV & URS & UFM & URM & RAL & URS \\
\hline Latitude $\left({ }^{\circ} \mathrm{S}\right)$ & -2758 & -2007 & -2648 & -2602 & -2710 & -2759 & -2032 & -2623 & -2322 & -2839 & -2812 \\
\hline Longitude ( $\left.{ }^{\circ} \mathrm{E}\right)$ & 15300 & 14810 & 15308 & 15303 & 15115 & 15320 & 13928 & 15305 & 15030 & 15156 & 15202 \\
\hline Mean temperature $\left({ }^{\circ} \mathrm{C}\right)$ & 19.6 & 24.2 & 20.1 & 20.3 & 19.1 & 20.2 & 25.4 & 20.3 & 22.9 & 15.2 & 17.5 \\
\hline Annual rainfall (mm) & 915 & 1010 & 1575 & 1138 & 676 & 1439 & 386 & 1696 & 947 & 770 & 710 \\
\hline Area $\left(\mathrm{km}^{2}\right)$ & 2854 & 21177 & 1094 & 2,967 & 48 & 1407 & 43343 & 869 & 189 & 2697 & 4423 \\
\hline Population (\#) & 55612 & 12518 & 78798 & 34019 & 10150 & 438473 & 20875 & 45214 & 59410 & 10515 & 21387 \\
\hline Population growth rate (\%) & 3.0 & 0.9 & 3.4 & 1.1 & 0.4 & 3.5 & -1.7 & 3.3 & 0.8 & 1.3 & 0.5 \\
\hline Population density & 19.5 & 0.6 & 72.1 & 11.5 & 212.2 & 311.7 & 0.5 & 52 & 315 & 3.9 & 4.8 \\
\hline Water connections (\#) & 6950 & 4587 & 34441 & 9961 & 4119 & 191030 & 6756 & 18971 & 22902 & 2483 & 7085 \\
\hline Pricing structure & $\begin{array}{r}\text { Two-part } \\
\text { tariff }\end{array}$ & $\begin{array}{r}\text { Fixed } \\
\text { with excess }\end{array}$ & $\begin{array}{r}\text { Two-part } \\
\text { tariff }\end{array}$ & $\begin{array}{r}\text { Multi-part } \\
\text { tariff }\end{array}$ & $\begin{array}{r}\text { Multi-part } \\
\text { tariff }\end{array}$ & $\begin{array}{r}\text { Two-part } \\
\text { tariff }\end{array}$ & $\begin{array}{r}\text { Multi-part } \\
\text { Tariff }\end{array}$ & $\begin{array}{r}\text { Two-part } \\
\text { tariff }\end{array}$ & $\begin{array}{r}\text { Fixed } \\
\text { no excess }\end{array}$ & $\begin{array}{r}\text { Two-part } \\
\text { tariff }\end{array}$ & $\begin{array}{r}\text { Two-part } \\
\text { tariff }\end{array}$ \\
\hline Basis for charge & $\begin{array}{r}\text { Meter } \\
\text { diameter }\end{array}$ & Fixed & Fixed & $\begin{array}{r}\text { Meter } \\
\text { diameter }\end{array}$ & Fixed & Fixed & Units & $\begin{array}{r}\text { Meter } \\
\text { diameter }\end{array}$ & Fixed & $\begin{array}{r}\text { Meter } \\
\text { diameter }\end{array}$ & $\begin{array}{r}\text { Meter } \\
\text { diameter }\end{array}$ \\
\hline Fixed/unit charge (\$) & - & 450 & - & - & - & - & - & - & 472 & - & - \\
\hline Water allowance $(\mathrm{kl})$ & - & 750 & - & - & - & - & - & - & Unlimited & - & - \\
\hline Excess charge $(\$ / \mathrm{kl})$ & - & 0.75 & - & - & - & - & - & - & 0.00 & - & - \\
\hline Access charge (\$) & 233.40 & - & 78 & 190 & 198 & 173 & 300 & 130 & - & 208 & 275 \\
\hline Consumption rate $(\$ / \mathrm{kl})$ & 0.82 & - & 0.78 & $<290 \mathrm{kl} @ 0.422$ & $<365 \mathrm{kl} @ 0.40$ & 0.70 & <1050k1@0.60 & 0.72 & - & 0.58 & 0.75 \\
\hline Consumption rate $(\$ / \mathrm{kl})$ & - & - & - & >290kl@1.158 & >365kl@0.90 & - & >1050k1@0.70 & - & - & - & - \\
\hline
\end{tabular}

Source: Department of Local Government, Planning, Sport and Recreation, Queensland local government comparative information 2002/03.

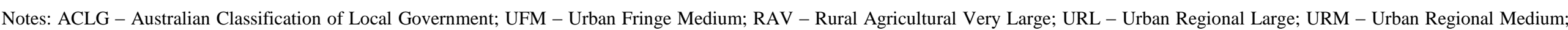

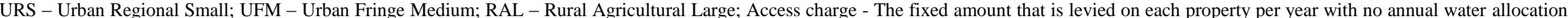

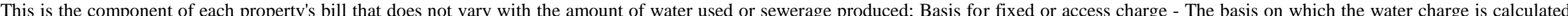

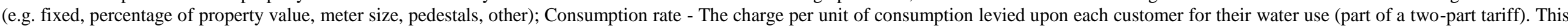

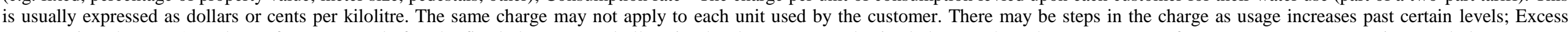

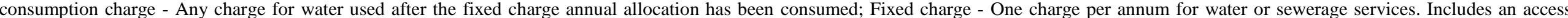

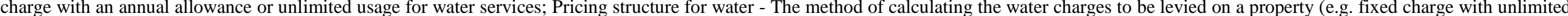

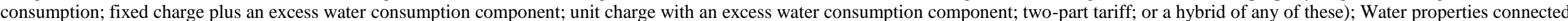
- The total number of properties connected to the service water system and separately billed for water supply; Population density - Population/area. 
Figure 1. Queensland local government areas, 2003.

Source: Queensland Government Department of Local Government and Planning

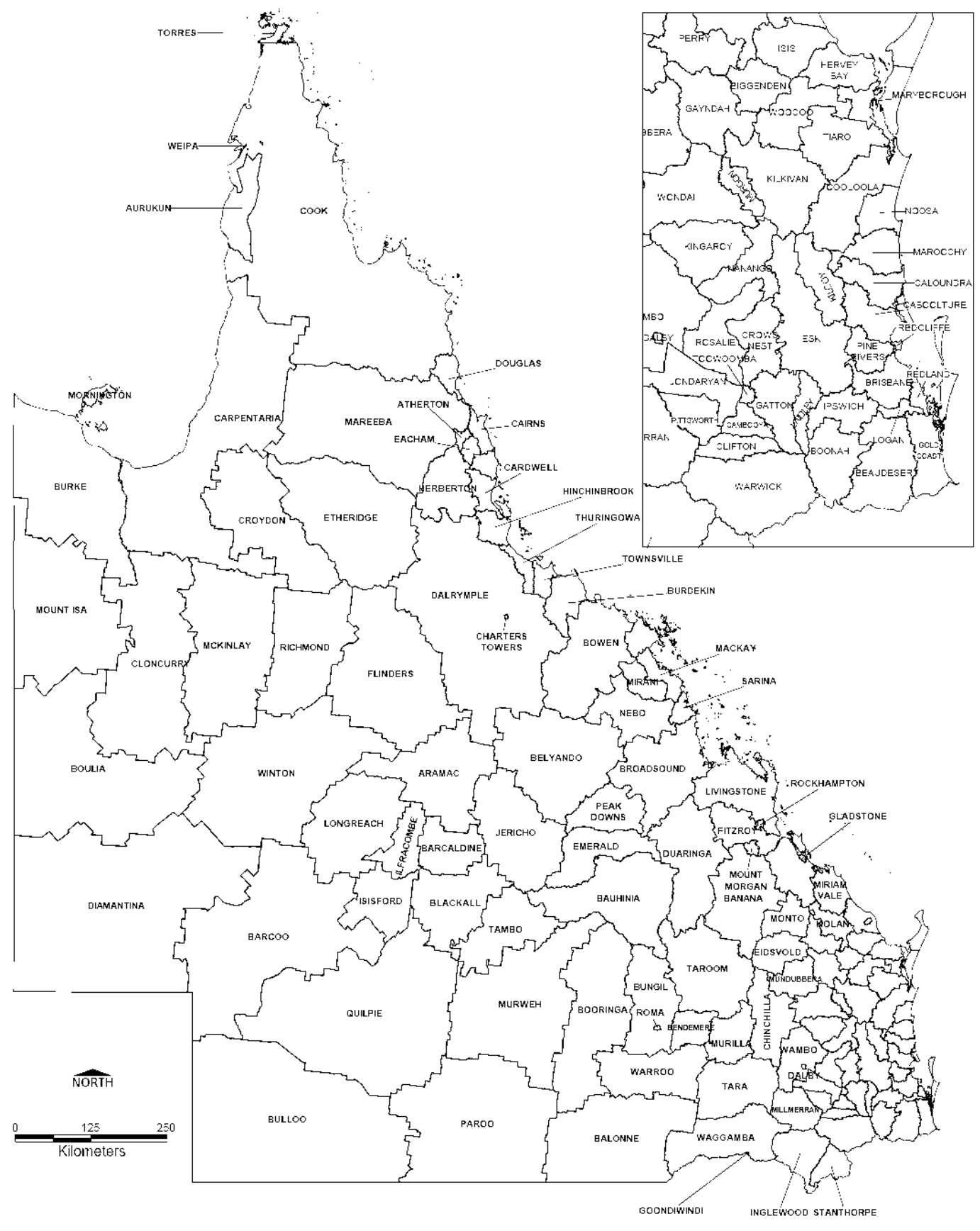


Table 2. Monthly descriptive statistics to August 2004.

\begin{tabular}{|c|c|c|c|c|c|c|c|c|c|c|c|c|}
\hline Statistic & $\begin{array}{l}\text { Demand } \\
(\mathrm{kl})\end{array}$ & $\begin{array}{c}\text { Marginal } \\
\text { price }(\phi / \mathrm{kl})\end{array}$ & $\begin{array}{c}\text { Average } \\
\text { price }(\phi / \mathrm{kl})\end{array}$ & $\begin{array}{c}\text { Average } \\
\text { daily } \\
\text { maximum } \\
\left({ }^{\circ} \mathrm{C}\right) \\
\end{array}$ & $\begin{array}{l}\text { Average } \\
\text { daily } \\
\text { rainfall } \\
(\mathrm{mm})\end{array}$ & Council & $\begin{array}{l}\text { Demand } \\
(\mathrm{kl})\end{array}$ & $\begin{array}{c}\text { Marginal } \\
\text { price }(\phi / \mathrm{kl})\end{array}$ & $\begin{array}{c}\text { Average } \\
\text { price }(\phi / \mathrm{kl})\end{array}$ & $\begin{array}{c}\text { Average } \\
\text { daily } \\
\text { maximum } \\
\left({ }^{\circ} \mathrm{C}\right) \\
\end{array}$ & $\begin{array}{l}\text { Average } \\
\text { daily } \\
\text { rainfall } \\
(\mathrm{mm}) \\
\end{array}$ & Council \\
\hline Mean & 47.05 & 37.24 & 82.07 & 25.95 & 2.63 & \multirow{4}{*}{ 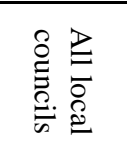 } & 42.33 & 55.53 & 94.38 & 24.87 & 3.52 & \multirow{4}{*}{ 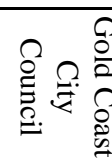 } \\
\hline Std. dev. & 27.45 & 30.61 & 34.00 & 4.31 & 2.81 & & 5.83 & 19.75 & 20.27 & 2.98 & 3.04 & \\
\hline Minimum & 17.29 & 0.00 & 4.65 & 13.94 & 0.00 & & 30.93 & 8.34 & 43.37 & 19.75 & 0.04 & \\
\hline Maximum & 156.68 & 95.00 & 183.45 & 39.40 & 30.53 & & 62.71 & 95.00 & 128.01 & 30.97 & 17.96 & \\
\hline Mean & 30.97 & 34.39 & 98.70 & 26.00 & 1.95 & \multirow{4}{*}{ 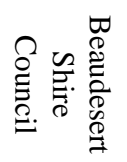 } & 110.56 & 53.41 & 77.01 & 31.61 & 1.47 & \multirow{4}{*}{ 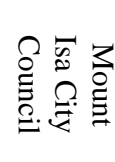 } \\
\hline Std. dev. & 6.11 & 40.79 & 49.61 & 3.40 & 1.91 & & 21.39 & 6.65 & 8.63 & 4.32 & 2.55 & \\
\hline Minimum & 19.17 & 0.00 & 39.72 & 20.23 & 0.04 & & 59.40 & 41.74 & 61.44 & 22.68 & 0.00 & \\
\hline Maximum & 47.54 & 82.00 & 183.45 & 32.24 & 7.92 & & 156.68 & 62.51 & 97.36 & 39.40 & 12.59 & \\
\hline Mean & 81.44 & 16.92 & 87.52 & 29.46 & 1.02 & \multirow{4}{*}{ 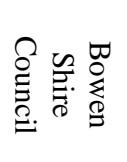 } & 33.51 & 67.45 & 100.14 & 25.21 & 4.08 & \multirow{4}{*}{ 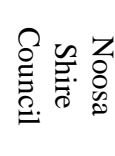 } \\
\hline Std. dev. & 15.64 & 9.95 & 28.48 & 3.21 & 1.76 & & 6.07 & 3.24 & 6.49 & 2.74 & 3.87 & \\
\hline Minimum & 46.92 & 0.00 & 63.90 & 24.08 & 0.00 & & 23.02 & 64.00 & 87.08 & 20.10 & 0.05 & \\
\hline Maximum & 108.58 & 31.83 & 141.95 & 34.66 & 7.21 & & 47.74 & 77.00 & 115.24 & 29.95 & 30.53 & \\
\hline Mean & 30.55 & 75.34 & 97.83 & 25.04 & 3.93 & \multirow{4}{*}{ 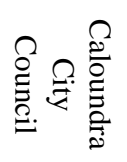 } & 90.68 & 0.00 & 39.58 & 28.44 & 1.71 & \multirow{4}{*}{ 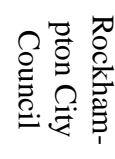 } \\
\hline Std. dev. & 6.39 & 0.96 & 4.93 & 2.92 & 3.36 & & 6.20 & 0.00 & 3.96 & 3.30 & 1.91 & \\
\hline Minimum & 19.87 & 75.00 & 89.43 & 19.84 & 0.06 & & 81.13 & 0.00 & 32.51 & 21.90 & 0.00 & \\
\hline Maximum & 46.21 & 78.00 & 110.72 & 30.19 & 23.40 & & 100.62 & 0.00 & 45.35 & 34.24 & 12.20 & \\
\hline Mean & 36.77 & 27.72 & 84.37 & 25.82 & 3.79 & \multirow{4}{*}{ 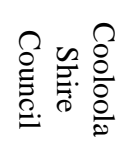 } & 23.79 & 17.23 & 47.69 & 21.43 & 1.91 & \multirow{4}{*}{ §. } \\
\hline Std. dev. & 7.59 & 20.01 & 18.53 & 2.99 & 3.25 & & 4.08 & 26.33 & 60.73 & 4.58 & 1.51 & \\
\hline Minimum & 22.55 & 0.00 & 32.75 & 20.06 & 0.03 & & 17.29 & 0.00 & 4.65 & 13.94 & 0.00 & \\
\hline Maximum & 65.39 & 65.81 & 106.85 & 30.71 & 23.25 & & 38.73 & 57.00 & 155.12 & 29.42 & 7.06 & \\
\hline Mean & 36.33 & 18.66 & 87.71 & 26.67 & 1.76 & \multirow{4}{*}{ 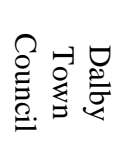 } & 33.58 & 37.08 & 96.10 & 23.99 & 1.71 & \multirow{4}{*}{ 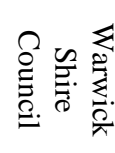 } \\
\hline Std. dev. & 10.00 & 12.28 & 19.84 & 4.56 & 1.62 & & 9.01 & 32.68 & 33.89 & 4.54 & 1.38 & \\
\hline Minimum & 21.27 & 0.00 & 64.09 & 18.06 & 0.00 & & 19.21 & 0.00 & 43.98 & 16.50 & 0.03 & \\
\hline Maximum & 77.02 & 42.90 & 131.08 & 33.69 & 6.93 & & 56.07 & 83.00 & 171.53 & 31.68 & 5.04 & \\
\hline
\end{tabular}

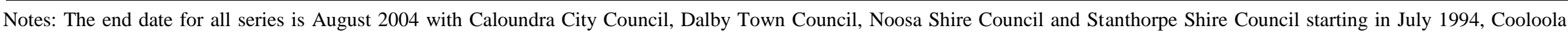

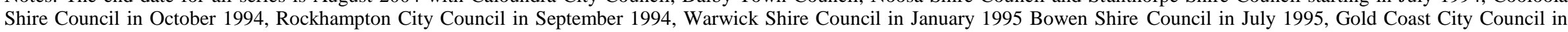
February 1996, Noosa Shire Council in July 1998 and Beaudesert Shire Council in July 1999. 
Table 3. Comparison of means.

\begin{tabular}{|c|c|c|c|c|c|c|}
\hline \multirow[b]{2}{*}{ Variable } & \multicolumn{2}{|c|}{$\begin{array}{l}\text { Tariff structure } \\
\text { means }\end{array}$} & \multicolumn{2}{|c|}{$\begin{array}{l}\text { Levene's test for equality of } \\
\text { variances }\end{array}$} & \multicolumn{2}{|c|}{$\begin{array}{l}\text { t-test for equality of } \\
\text { means }\end{array}$} \\
\hline & $\begin{array}{l}\text { Fixed and } \\
\text { fixed with } \\
\text { excess }\end{array}$ & $\begin{array}{l}\text { Two-part } \\
\text { and multi- } \\
\text { part }\end{array}$ & $F$-statistic & $p$-value & $t$-statistic & $p$-value \\
\hline Demand (kl) & 51.116 & 42.752 & 21.110 & 0.000 & 4.899 & 0.000 \\
\hline Marginal price $(\varnothing / \mathrm{kl})$ & 11.431 & 64.460 & 34.113 & 0.000 & -55.488 & 0.000 \\
\hline Average price $(\phi / \mathrm{kl})$ & 60.107 & 105.229 & 76.735 & 0.000 & -28.456 & 0.000 \\
\hline Average daily maximum $\left({ }^{\circ} \mathrm{C}\right)$ & 25.979 & 25.927 & 1.365 & 0.243 & 0.191 & 0.849 \\
\hline Average daily rainfall (mm) & 2.325 & 2.945 & 23.407 & 0.000 & -3.506 & 0.000 \\
\hline
\end{tabular}

Table 4. Estimated regression models.

\begin{tabular}{|c|c|c|c|c|c|c|c|c|c|c|c|c|}
\hline \multirow[b]{2}{*}{ Variable } & \multicolumn{4}{|c|}{ Common effects } & \multicolumn{4}{|c|}{ Fixed effects } & \multicolumn{4}{|c|}{ Random effects } \\
\hline & Coefficient & Std. error & $p$-value & Elasticity & Coefficient & Std. error & $p$-value & Elasticity & Coefficient & Std. error & $p$-value & Elasticity \\
\hline Constant & -31.775 & 4.341 & 0.000 & & - & - & - & - & 25.878 & 5.421 & 0.000 & \\
\hline Marginal price & -0.142 & 0.022 & 0.000 & -0.112 & 0.020 & 0.012 & 0.089 & 0.016 & 0.018 & 0.014 & 0.194 & 0.014 \\
\hline Temperature & 3.515 & 0.176 & 0.000 & 1.939 & 0.888 & 0.082 & 0.000 & 0.490 & 0.900 & 0.075 & 0.000 & 0.497 \\
\hline Rainfall & -2.718 & 0.338 & 0.000 & -0.152 & -1.083 & 0.160 & 0.000 & -0.060 & -1.092 & 0.104 & 0.000 & -0.061 \\
\hline R-squared & 0.393 & - & - & - & 0.911 & - & - & - & 0.909 & - & - & - \\
\hline Adj. R-squared & 0.391 & - & - & - & 0.910 & - & - & - & 0.909 & - & - & - \\
\hline$F$-statistic & 218.250 & - & 0.000 & - & 785.974 & - & 0.000 & - & - & - & - & - \\
\hline$F$-test & - & - & - & - & 588.344 & - & 0.000 & - & 516.076 & - & 0.000 & - \\
\hline Hausman test & - & - & - & - & - & - & - & - & 6466.191 & - & 0.000 & - \\
\hline Constant & -16.467 & 4.580 & 0.000 & & - & - & - & - & 32.533 & 4.071 & 0.000 & \\
\hline Average price & -0.225 & 0.020 & 0.000 & -0.392 & -0.072 & 0.007 & 0.000 & -0.126 & -0.073 & 0.010 & 0.000 & -0.128 \\
\hline Temperature & 3.424 & 0.169 & 0.000 & 1.889 & 0.881 & 0.080 & 0.000 & 0.486 & 0.902 & 0.073 & 0.000 & 0.498 \\
\hline Rainfall & -2.627 & 0.317 & 0.000 & -0.147 & -1.080 & 0.157 & 0.000 & -0.060 & -1.095 & 0.102 & 0.000 & -0.061 \\
\hline R-squared & 0.445 & - & - & - & 0.916 & - & - & - & 0.912 & - & - & - \\
\hline Adj. R-squared & 0.443 & - & - & - & 0.914 & - & - & - & 0.912 & - & - & - \\
\hline$F$-statistic & 269.831 & - & 0.000 & - & 834.964 & - & 0.000 & - & - & - & - & - \\
\hline$F$-test & - & - & - & - & 565.542 & - & 0.000 & - & 482.279 & - & 0.000 & - \\
\hline Hausman test & - & - & - & - & - & - & - & - & 6905.473 & - & 0.000 & - \\
\hline
\end{tabular}

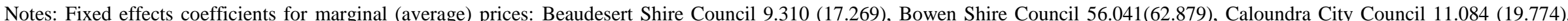

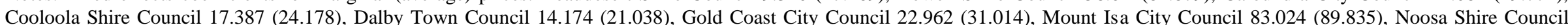

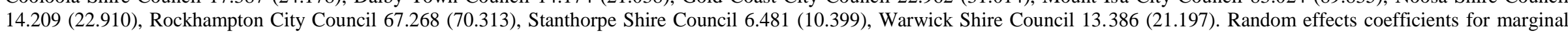

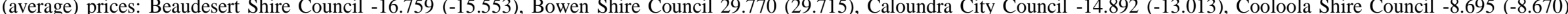

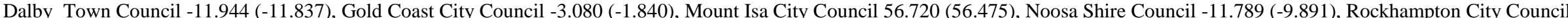
40.958 (37.070), Stanthorpe Shire Council -19.555 (-22.366), Warwick Shire Council -12.668 (-11.611) 
Table 5. Estimated regression models.

\begin{tabular}{lrrrr}
\hline Variable & Coefficient & Std. error & $p$-value & \multicolumn{1}{c}{ Elasticity } \\
\hline Average price & -0.060 & 0.022 & 0.005 & -0.105 \\
Temperature & 0.835 & 0.093 & 0.000 & 0.461 \\
Rainfall & -0.970 & 0.202 & 0.000 & -0.054 \\
Two-part tariff & 19.354 & 6.446 & 0.003 & \\
Two-part tariff $\times$ average price & -0.142 & 0.044 & 0.001 & -0.154 \\
Two-part tariff $\times$ temperature & -0.031 & 0.162 & 0.847 & -0.008 \\
Two-part tariff $\times$ rainfall & -0.065 & 0.280 & 0.817 & -0.002 \\
\hline R-squared & 0.918 & - & - & - \\
Adj. R-squared & 0.917 & - & - & - \\
\hline
\end{tabular}

Fixed effects coefficients: Beaudesert Shire Council 18.601, Bowen Shire Council 63.109, Caloundra City Council 14.908, Cooloola Shire Council 23.222, Dalby Town Council 20.294, Gold Coast City Council 29.061, Mount Isa City Council 82.885, Noosa Shire Council 18.350, Rockhampton City Council 70.983, Stanthorpe Shire Council 10.973, Warwick Shire Council 20.141 . 